\title{
General Equilibrium Impacts of Technological Change under Different Market Structures: A Comparison of Supply Managed and Other Primary Agricultural Markets in Canada
}

\author{
Pahan Prasada*
}

\begin{abstract}
Market impacts of technological change in Canadian agriculture are measured within a CGE framework using 2001 input-output data with agriculture disaggregated to six sectors and thirteen commodities. Technological change is modelled as productivity rises in the use of intermediate inputs and of primary factors. Impacts on output, intermediate use of output, foreign trade, final consumption, returns to primary factors and relative price are calculated for primary and processed food products. Impacts of technological change can be summarised into two general outcomes. First, supply managed sectors respond to technological change differently than other agricultural sectors. In the former, economic rents generated from quotas increase while in the latter, outputs, exports, and final consumption increase along with declines of relative supply prices. Second, large relative price declines for other commodities lead to consumer gains.
\end{abstract}

\section{Introduction}

Economic assessments of impacts of new technologies can use several approaches. Many studies have used the partial-equilibrium model of Alston et al., (1995) which examines market consequences of new technologies and calculates changes in producer and consumer welfare. Partial equilibrium multi-stage production models after Martin and Alston (1994) have also been used in number of occasions to capture the impacts of research induced technological change in agriculture systems. An alternative approach is available in applied general equilibrium models, which provide economy-wide estimates of impacts consistent with microeconomic theory Several CGE applications have modeled impacts of biotechnological innovations using Global Trade Analysis Project (GTAP) CGE model of global trade analysis (Huang et al., 2003; Stone et al., 2003). CGE models usually focus on cost reduction (input saving) and output expansion from the new technology and derive general equilibrium price, production, trade, and

Lecturer, Department of Agricultural Economics and Business Management, Faculty of Agriculture, University of Peradeniya, Sri Lanka. 
welfare impacts resulting from total factor productivity or factor-biased technical change (Elbehri and MacDonald, 2003).

An extensive collection of partial equilibrium analyses of the impacts of 'research and development' investments for various commodities exists for Canada (Alston et al., 2000). They report the impacts of research and development as marginal or average rates of return values in the approximate range of $30-100 \%$. Multi-sectoral linear programming models have predicted estimates of rate of returns of comparatively lower (by about 10\%) magnitude (Klein et al., 1994). To our knowledge, there has been no computable general equilibrium analysis of the impacts of technological change in Canadian agriculture to date (we are certain of the absence of such performed using data after year 2000).

This paper reports general equilibrium results of a modeling exercise evaluating technological change in Canadian agriculture. The focus is on primary agricultural production taking into account supply management restrictions in dairy and poultry production. Technological change is modeled as input savings in the use of purchased inputs (intermediate inputs as per Statistics Canada sectoral input classification) and of primary factors.

A computable general equilibrium (CGE) model evaluates the impacts of technological change modeled independently in supply managed sector and other primary agricultural sector on the primary agricultural commodity markets. Output, intermediate demand for commodities, exports/imports and relative supply prices are the considered market impacts. The returns to primary factors in the two sectors are also evaluated.

The objective is to measure the general equilibrium impacts of technological change in the primary agricultural commodity markets. Inputoutput and final demand data for 2001 published by Statistics Canada is used. Simulations provide impacts at the individual commodity market level. I believe that evaluation of returns to primary factors in the two sectors under technological change provides a comparable general equilibrium estimate for the producer surplus measure in the partial equilibrium literature.

Results of the simulations show important effects of technological change. Productivity improvement in the primary agricultural production has a number of impacts for primary products that are not supply-controlled via quotas. The lower supply prices make primary products cheap inputs for processing sectors, spilling over the impact of technological change in primary production to the processing industries which in turn will produce final goods at lower prices. When primary products are exported the lower domestic supply prices make the Canadian exporters competitive in world 
trade. However, supply managed commodity markets show an accumulation of quota rents to the farmers as the only significant impact.

\section{Study Context}

\section{Canadian Agriculture}

Agriculture in Canada has been an important sector throughout the history of the country as a source of food and exports. The agriculture and agri-food system accounted for $8.1 \%$ of total Gross Domestic Product (GDP) in 2004 (primary production and processing together making 3.4\%). The overall system has been growing in size at $2.4 \%$ per annum (Agriculture and Agri-Food Canada, 2006).

Agriculture performs several inter-sectoral functions which are important for the overall economic growth. Primary agriculture is a large user of energy products and repair and maintenance services. For example in 2002, it purchased $7.4 \%$ of all industrial diesel oil used, accounting for $5.8 \%$ of the total value of diesel production in Canada (Agriculture and Agri-Food Canada, 2006). At the same time the agriculture and agri-food sector is a key supplier to other industries.

Supply management in dairy and poultry has been a distinct feature of Canadian agriculture since 1970s. Supply management refers to the systematic use of production and border controls to manage national supplies to satisfy projected demand at a target price. The goal of controlling supply so the market clears at the target price is to stabilize and enhance dairy farm incomes. In Canada, the federal government sets the price of industrial milk at a level determined by cost of production formulae. To maintain the predetermined price, the level of industrial milk production and imports of industrial milk products must be restricted. The National Milk Marketing Plan sets out the framework to calculate the quantity of industrial milk needed to meet domestic requirements and any planned exports. The quantity supplied of industrial milk in each province is restricted using a Market Share Quota. Each province's Market Share Quota is determined using its historical share of national industrial milk production. Quota holdings in the supply managed industries have grown significantly over time. In 2004, the average dairy farm had around 1.2 million dollars worth of quota compared to an approximate value of 300 thousand dollars in 1994 and the average poultry farm around 1.5 million dollars compared to an approximate value of 400 thousand dollars in 1994. In each case, on average, value of quota accounted for 50\% and 53\% of total farm assets respectively (Agriculture and Agri-Food Canada, 2006). 
The large strides in technology in recent years have brought about considerable transformation in agricultural production activity in Canada. Average farm size has been continuously increasing while the number of farms has been decreasing (Schmitz et al., 2002). Labor has been freed from agriculture while the production processes have been more material using. Factor productivity indicators in agriculture have been improving regularly and for the six years from 1997 to 2003 multifactor productivity has been growing at 3\% per annum (Agriculture and Agri-Food Canada, 2006). Over the last 20 years, cattle carcass weights have increased by $33 \%$. Larger litter sizes, more litters per year, and heavier carcass weights have resulted in a $49 \%$ increase in pork production per sow since 1990. Crop yields also have risen steadily. Average annual corn yield has risen from 5 tons per hectare to more than 7.5 tons per hectare over the 30 years from 1970 to 2000, according to agricultural census.

\section{Data and Model}

Data is from the L (link) level classification of 2001 input-output data and final demand tables for Canada published by Statistics Canada ${ }^{1}$ (Statistics Canada, 2006). For the computable general equilibrium (CGE) analysis reported here, above data was aggregated to 25 commodities, 20 sectors. Representative agent's final demand is four-fold: final consumption, government consumption, investment and net exports. 3 Primary factors are endowed to the agent.

Agricultural detail in the model includes 13 commodities representing total Canadian agriculture: 9 primary commodities and 4 processed commodities. Primary commodities include cattle and calves, swine, other livestock, grains, oilseeds, fruits and vegetables as non supply managed goods and poultry (chicken and turkey combined), eggs, and raw milk as supply managed goods. This paper looks at the general equilibrium response of the commodity markets of these two groups to technological change.

The CGE model is a single country version of the Basic Model of Regional Trade (BMRT) by Wigle and Snoddon (2004). Each production activity is modeled by a nested (hierarchical) production function, which enable the special functional forms as, for instance, constant elasticity of substitution (CES), Cobb-Douglas or Leontief functions to be contained within CES functions, and many layers of hierarchy can be utilized (Shoven and Whalley, 1992). Further, this structure allows a flexible representation of the degree of substitution between inputs to the production process

1 The detailed input output data is available from Statistics Canada at <http://www.statcan.gc.ca/pub/15-201-x/2008000/5005546-eng.htm> 
(Rutherford, 1994). Domestic and imported goods in production and consumption aggregate under Armington assumption (Armington, 1969) with constant elasticities of substitution. Domestic output and exports are transformed with constant elasticity. Consumer Preferences are CobbDouglas. Appendix 1 contains the detailed equation system used in the model. The model was implemented in GAMS and MPSGE software systems. Appendix 2 contains the input, output and final demand tables after the aggregation of the L level data by the author.

Supply management regime in dairy and poultry is modeled as an endogenous tax (Benjamin et al., 1999; van Meijl and van Tongeren, 2002) facilitating a switch from a binding to a non-binding status. Thus, the model adjusts endogenously both the quantity and the quota rent.

\section{Simulations}

As mentioned previously, technological change is modeled as productivity increases in inputs. It is implemented in the model as $10 \%$ savings of inputs in the counterfactual simulations. Two groups of inputs are considered: intermediate goods and primary factors (see table 1 for detailed allocation of each input category into supply managed, non supply managed and processing agriculture). Any input other than a primary factor used in the production is considered as an intermediate input. Thus, any of the 25 commodities could be an intermediate input in a given production activity. Primary factors are capital, labour (wages, salaries and supplementary labour income) and mixed income (i.e income of unincorporated businesses).

The two types of technological change (i.e. rise in productivity of intermediate input use and of primary factor use) constitute modeling scenario (1) and (2) respectively. Scenarios (1) and (2) are independently implemented in supply managed production and other primary production. When Supply managed sector is subjected to technological change, the situation is identified as 'case $\mathrm{A}$ ' and when rest of primary agricultural sector undergoes technological change, the situation is identified as 'case B'. This separation and independent treatment of supply managed and other sectors is motivated by the strategic importance of the supply managed sector (dairy and poultry) in Canadian agriculture. Further, the statistics indicate that the interlinkages between the supply managed sector and other agricultural sectors are very few. 
6

Table 1: $\quad$ Intermediate input and primary factor use (Million dollars)

\begin{tabular}{|c|c|c|c|}
\hline & \multicolumn{3}{|c|}{ Sectors } \\
\hline & $\begin{array}{c}\text { Supply } \\
\text { managed }\end{array}$ & $\begin{array}{c}\begin{array}{c}\text { Other } \\
\text { agriculture }\end{array} \\
\end{array}$ & Processing \\
\hline \multicolumn{4}{|l|}{ Intermediate Inputs } \\
\hline Cattle and calves & 35 & 1,317 & 4,804 \\
\hline Swine & & 42 & 3,086 \\
\hline Poultry & 217 & 173 & 1,334 \\
\hline Other animals & & & 100 \\
\hline Raw milk & & & 4,144 \\
\hline Eggs & 1 & & 286 \\
\hline Red meat & & & 2,446 \\
\hline Poultry meat & & & 1,450 \\
\hline Processed dairy & & & 1,860 \\
\hline Grains & 387 & 1,406 & 1,899 \\
\hline Fruits and vegetables & 74 & 267 & 906 \\
\hline Oil seeds & 35 & 127 & 1,258 \\
\hline $\begin{array}{l}\text { Other primary agricultural } \\
\text { goods }\end{array}$ & 465 & 1,862 & 2,324 \\
\hline Other processed food & 894 & 3,272 & 8,604 \\
\hline Agricultural support services & 611 & 1,976 & \\
\hline Forestry products & & 27 & \\
\hline Mining products & & 11 & 53 \\
\hline Utilities & 125 & 817 & 899 \\
\hline Fuel & 99 & 1,088 & 507 \\
\hline $\begin{array}{l}\text { Secondary manufacturing } \\
\text { goods }\end{array}$ & 181 & 3,506 & 6,070 \\
\hline $\begin{array}{l}\text { Machinery, equipment, } \\
\text { vehicles }\end{array}$ & 27 & 339 & 37 \\
\hline Construction goods & 143 & 725 & 98 \\
\hline Transport services & 179 & 692 & 1,775 \\
\hline Commercial services & 994 & 4,084 & 11,870 \\
\hline Social services & 20 & 72 & 1 \\
\hline \multicolumn{4}{|l|}{ Primary Factors } \\
\hline Labour & 494 & 3,023 & 10,201 \\
\hline Capital & 1,953 & 6,988 & 12,155 \\
\hline Other (mixed returns) & 366 & 1,311 & 78 \\
\hline
\end{tabular}

Source: Authors' aggregation using data by Statistics Canada (2006) 


\section{Results and Discussion}

Table 2 reports the results from the benchmark solution of the model prior to the incorporation of technological change scenarios. It lists the market variables for each primary commodity market in the model.

Table 2: $\quad$ Benchmark results (Millions of dollars)

\begin{tabular}{lrrrrr}
\hline \multicolumn{1}{c}{ Commodity } & Output & $\begin{array}{c}\text { Intermediate } \\
\text { Use }\end{array}$ & Exports & Imports & $\begin{array}{c}\text { Final } \\
\text { Consumption }\end{array}$ \\
\hline Cattle and calves & 7,791 & 6,164 & 1,388 & - & - \\
Swine & 3,843 & 3,133 & 525 & - & - \\
Other live animals & 386 & 121 & 86 & - & - \\
Grains & 6,092 & 3,700 & 2,383 & - & - \\
Oilseeds & 2,028 & 1,425 & 1,028 & - & 3,199 \\
Fruits and & 3,542 & 1,786 & - & 1,424 & 9 \\
vegetables & & & - & - & - \\
Raw milk & 4,155 & 4,146 & - & 7 & 303 \\
Poultry & 1,761 & 1,727 & - & 38 & \\
Eggs & 551 & 286 & - & & \\
\hline
\end{tabular}

\section{Individual Market Results from Counterfactual Simulations}

This section documents the results of the simulations for each commodity market. The logic of presentation is summarised in the figure 1 . The two types of inputs (intermediate goods and primary factors) contribute to the production of any commodity. Technological change is modeled via these two input types. Output of each commodity is end-used as intermediate input or net export. Relative change of each variable (output, intermediate use, export/import and relative price) is evaluated by comparing the benchmark equilibrium and counterfactual equilibrium. Percentage changes of each variable from the benchmark solution is calculated and reported.

Impacts of technological change in supply managed sector on non supply managed commodities are insignificant. Similarly, impacts of technological change in non supply managed sector on supply managed commodities are insignificant as well. These results are not reported. 
Figure 1: $\quad$ An illustration of the logic behind modeling market effects using cattle and calves market as an example

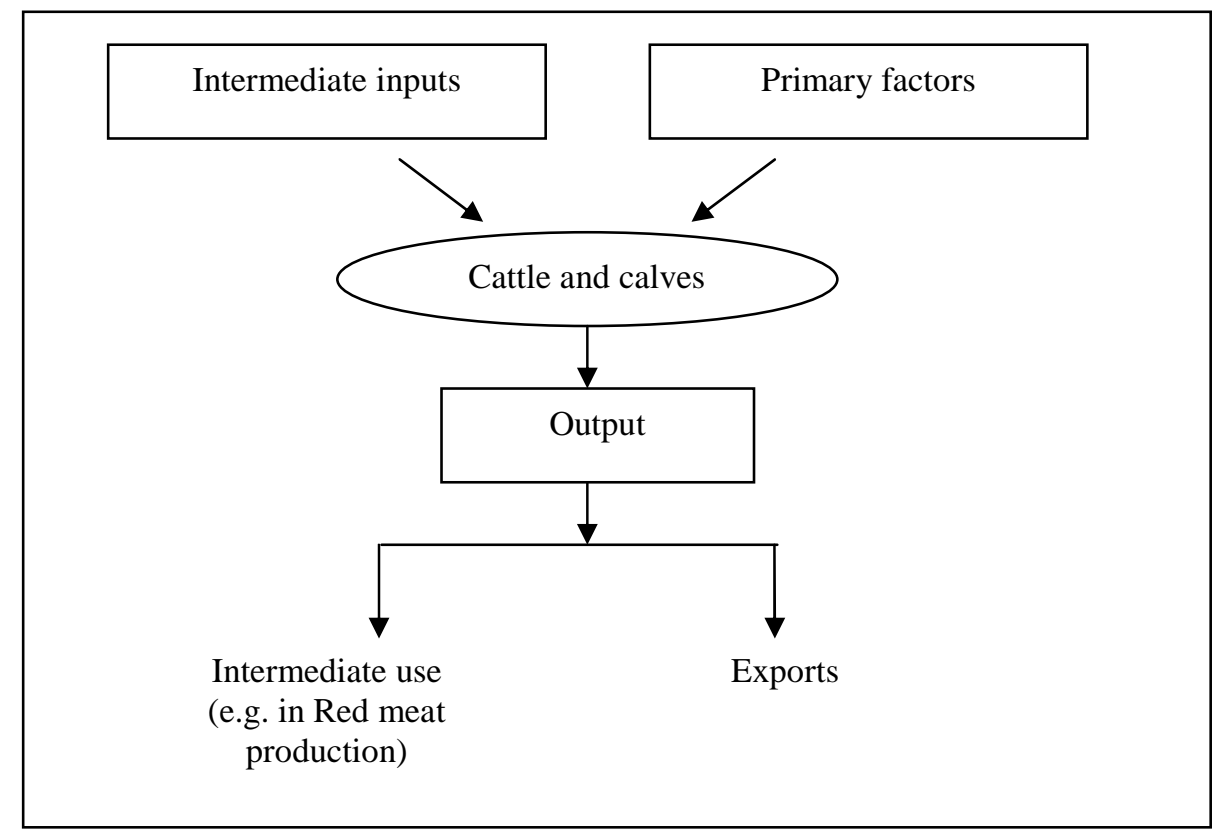

\section{Non Supply Managed Commodities}

Table 3 lists the percentage changes of market effects for non supply managed commodities due to the two technological change scenarios. Outputs of all the six commodities increase for both scenarios. The increased output is largely exported. Intermediate demand for the commodities from other sectors increase slightly. In the case of fruits \& vegetables, where a significant portion of output is consumed as final goods, final consumption rises by $7.6 \%$ and $3.2 \%$ for scenarios 1 and 2 respectively. Relative supply prices decrease making exports more competitive. Lower supply prices of the primary products make them cheap inputs for processing sectors, spilling over the impact of technological progress to secondary markets. Technological change in the use of intermediate inputs has a greater impact than that of primary factors, in terms of output, exports and relative price.

Counterfactual results for the 6 non supply managed commodities show significant total gains from technological change. Productivity increase by $10 \%$ in the use of purchased inputs (intermediate inputs) results in growth of non supply managed primary agriculture by 1616 million dollars via output expansion. For corresponding productivity increase in the use of primary factors, growth is 782 million dollars. The primary commodity export 
9

increases in either case of technological change contribute by 1034 and 409 million dollars respectively to Canadian agricultural trade surplus.

Table 3: $\quad$ Market effects for non supply managed commodities (Percentage changes from benchmark)

\begin{tabular}{|c|c|c|c|c|c|c|c|c|c|c|}
\hline & \multicolumn{2}{|c|}{ Output } & \multicolumn{2}{|c|}{$\begin{array}{l}\text { Intermediate } \\
\text { use }\end{array}$} & \multicolumn{2}{|c|}{ Exports } & \multicolumn{2}{|c|}{ Imports } & \multicolumn{2}{|c|}{ Relative price } \\
\hline & $(1)^{*}$ & (2) & (1) & (2) & (1) & (2) & (1) & (2) & (1) & (2) \\
\hline $\begin{array}{l}\text { Cattle \& } \\
\text { calves }\end{array}$ & 5.5 & 2.8 & 1.2 & 1.4 & 20.8 & 8.4 & - & - & -13.3 & -5.6 \\
\hline $\begin{array}{l}\text { Swine } \\
\text { Other }\end{array}$ & 5.7 & 2.2 & 2.1 & 0.6 & 21.3 & 9.3 & - & - & -13.5 & -6.9 \\
\hline livestock & 9.4 & 4.1 & 2.0 & 0.6 & 17.3 & 7.4 & - & - & -7.4 & -3.6 \\
\hline Grains & 7.6 & 4.1 & 0.1 & 2.1 & 18.4 & 7.1 & - & - & -9.7 & -3.2 \\
\hline Oilseeds & 9.0 & 4.1 & 1.4 & 1.3 & 15.3 & 6.3 & - & - & -7.5 & -3.1 \\
\hline $\begin{array}{l}\text { Fruits } \& \\
\text { vegetables }\end{array}$ & 8.1 & 3.7 & 0.8 & 1.3 & - & - & -1.6 & -0.2 & -9.5 & -4.2 \\
\hline
\end{tabular}

Scenario number

\section{Supply Managed Commodities}

The supply managed commodity markets fail to show significant general equilibrium impacts in output and intermediate use. The endogenous tax in the model captures the quota rents due to technological change in factor use for the two scenarios (Table 4). Significant increments in quota rents are observed for the three commodities. Technological change in the use of intermediate inputs appears to have a larger impact on the quota rents than that of primary factors. Under output controls and price controls (and accompanying trade restrictions), quota rents capture the impact of productivity increases in factor use. Value of quota rents accruing as a result of technological change are in fact comparable to value of output gains in unregulated commodity markets measured as a percentage of the sector's size (nearly $5 \%$ in either case).

Table 4: Quota rent increases resulting from productivity change (Millions of Dollars)

\begin{tabular}{lrr}
\hline \multirow{1}{*}{ Commodity } & \multicolumn{2}{c}{ Quota rent increase } \\
\cline { 2 - 3 } & \multicolumn{1}{c}{$(\mathbf{1})^{*}$} & $(\mathbf{2})$ \\
\hline Raw milk & 273.783 & 203.617 \\
Poultry & 0 & 65.749 \\
Eggs & 39.783 & 19.654 \\
\hline
\end{tabular}

${ }^{*}$ Scenario number 


\section{Impact on the Total Agricultural Sector}

Percentage changes in market impacts for all agricultural markets in the model were aggregated by weighted averaging (weights reflecting the relative output share in the total sector) to reflect the total impact for each 'case' and each 'scenario' of technological change. Results appear in table 5. Technological change in supply managed sector has insignificant impact on the overall agricultural sector while the same in other primary agriculture has a larger impact in increasing agricultural output, increasing exports, reducing imports and driving down the relative supply prices. Again, the intermediate input scenario has a higher impact in output, exports/imports and relative price compared to primary factor scenario.

Table 5: $\quad$ Percentage changes of impacts on the total agricultural sector

\begin{tabular}{|c|c|c|c|c|c|c|c|c|c|c|}
\hline & \multicolumn{2}{|c|}{ Output } & \multicolumn{2}{|c|}{$\begin{array}{c}\text { Intermediate } \\
\text { use }\end{array}$} & \multicolumn{2}{|c|}{ Exports } & \multicolumn{2}{|c|}{ Imports } & \multicolumn{2}{|c|}{$\begin{array}{l}\text { Relative } \\
\text { price }\end{array}$} \\
\hline & (1) ${ }^{*}$ & (2) & (1) & (2) & (1) & (2) & (1) & (2) & (1) & (2) \\
\hline Case A & 0.1 & 0 & $\begin{array}{l}-0.1 \\
\end{array}$ & 0 & 0.5 & -0.1 & -0.1 & 0.1 & -0.2 & 0 \\
\hline Case B & 2.5 & 1.3 & 0.8 & 1.0 & 12.9 & 5.0 & -1.2 & -0.1 & -3.6 & -1.4 \\
\hline
\end{tabular}

Scenario number

\section{Returns to Primary Factors}

Returns to primary factors in agricultural sectors produce an estimate of producer welfare in those sectors (table 6). Cross effects (i.e. change of returns to primary factors in supply managed sector due to technological change in other primary sector etc.) are insignificant and not reported. The lower returns to primary factors in supply managed sector (case A) are compensated by the higher rents accruing on quota which act as an endowment to the farmers in this sector. However, increase of factor returns by $9 \%$ for a given endowment of primary factors in the unregulated sector show the beneficial impacts to owners of capital and labour even though the conventional wisdom anticipates a release of capital and labour from agriculture as the technology advances.

Table 6: Percentage changes in returns to primary factors due to technological change

\begin{tabular}{lcc}
\hline & \multicolumn{2}{c}{ Returns to primary factors } \\
\cline { 2 - 3 } & $(\mathbf{1})^{*}$ & $(\mathbf{2})$ \\
\hline Case A & 1 & -10 \\
Case B & 9 & -6 \\
\hline
\end{tabular}

*Scenario number 


\section{Conclusion}

Results of the counterfactual experiments highlight the distinct differential market impacts that result from the presence and absence of supply management. The overall general equilibrium response in any single commodity market appears to be comparable as a ratio to its size, but the way in which the impact manifests differs. In supply managed commodities, the impacts of technological change (whether in the use of intermediate inputs or of primary factors) are captured in the quota rents while in rest of primary agriculture, outputs and exports expand considerably, and relative supply prices decline. The general equilibrium outcome that quota rents freezes the spillovers of technological change and retain the gains to the producers is also in conformity with several early partial equilibrium analyses on the Canadian dairy and poultry sector, i.e. Arcus (1981); Barichello (1981); Veeman (1982) (These were some of the first studies carried out to assess the economic impact of supply management). Returns to primary factors are also higher for non supply managed commodity production. However, the fact that quota rents act as an asset to supply managed farmers, offsets this disparity to a certain extent. From the general equilibrium results, it can be concluded that supply management limits the spill-over effects of technological change significantly, thus reducing the social welfare gains. In other commodities, the overall impact can be considered socially beneficial. The results obtained here extend the understanding about the economic outcomes of supply control program in Canada and elsewhere. In addition to the already known negative impacts of supply control, i.e. efficiency losses, we display the potential freezing effect production quotas can have on the incidence of technological change.

\section{Acknowledgements}

I gratefully acknowledge the advice and the guidance of my supervisors Professors Maury Bredahl, Glenn Fox and Randall Wiggle.

\section{References}

Agriculture and Agri-Food Canada (AAFC). (2006). An Overview of the Canadian Agriculture and Agri-food System. Publication 10013E. Ottawa: Research and Analysis Directorate, Agriculture and AgriFood Canada.

Alston, J., C. Chan-Kang, M. Marra, P. Pardey, and T. Wyatt (2000). A Metaanalysis of Rates of Return to Agricultural R\&D, Ex Pede Herculem? Research Report 113, Washington, DC: International Food Policy Research Institute. 
Alston, J.M., G.W. Norton and P.G. Pardey (1995). Science under Scarcity: Principles and Practice for Agricultural Research Evaluation and Priority Setting. Ithaca, NY: Cornell University Press.

Arcus. P.L. (1981). Broilers and Eggs. Economic Council of Canada Technical Report No. E13. Ottawa.

Armington, P.S. (1969). A Theory of Demand for Products Distinguished by Place of Production. IMF Staff Papers, 16(1): 159-176.

Barichello. R.R. (1981). The Economics of Canadian Dairy 1ndustry Regulation. Economic Council of Canada, Technical Report No. E12.

Benjamin, C., A. Gohin, and H. Guyomard (1999). The Future of European Union Dairy Policy. Canadian Journal of Agricultural Economics, 47(5): 91-101.

Elbehri, A. and S. MacDonald (2003). Transgenic Cotton and Crop Productivity: A General Equilibrium Analysis for West and Central Africa. Paper Prepared for Presentation at the 6th International Conference on Global Economic Analysis, The Hague, Netherlands, June 12-14, 2003.

Huang, J., R. Hu, H. van Meijil, and F. van Tongeren (2003). Biotechnology Boosts to Crop Productivity in China and its Impact on Global Trade. Paper presented at the 5th International Conference on Global Economic Analysis, Taiwan, June.

Klein, K.K., B. Freeze, J.S. Clark and G. Fox (1994). Returns to Beef Research in Canada: A Comparison of Time Series and Mathematical Programming Approaches. Agricultural Systems, 46: 443-459.

Martin, W.J. and J.M. Alston (1994). A Dual Approach to Evaluating Research Benefits in the Presence of Trade Distortions. American Journal of Agricultural Economics, 76: 26-35.

Rutherford, T.F. (1994). Applied General Equilibrium Modeling with MPSGE as a GAMS Subsystem in GAMS/MPSGE and GAMS/MILES User Notes T. Rutherford (eds.). Washington: GAMS Development Corporation.

Schmitz, A., W.H. Furtan, and K. Baylis (2002). Agricultural Policy, Agribusiness and Rent-Seeking Behaviour. Toronto: University of Toronto Press. 
Shoven, J. and Whalley, J. (1992). Apply General Equilibrium. Cambridge, UK: Cambridge University Press.

Statistics Canada (2006). The Input-Output Structure of the Canadian Economy. Ottawa: Input-Output Division, Statistics Canada.

Stone, S., A. Matysek, and A. Dolling (2003). The Implications of GMOs for Australian Trade. Paper Presented at the 5th Conference on Global Economic Analysis, Taiwan, June.

Van Meijl, H. and F. van Tongeren (2002). The Agenda 2000 CAP Reform, World Prices and GATT-WTO Export Constraints. European Review of Agricultural Economics, 29(4): 445-470.

Veeman. M.M. (1982). Social Costs of Supply-Restricting Marketing Boards. Canadian Journal of Agricultural Economics, 30 (March 1982): 2136.

Wigle, R. and T. Snoddon (2004). Basic Model of Regional Trade (BMRT). Canadian Regional Economic Analysis Project (CREAP). Wilfrid Laurier University and University of Waterloo, Canada. 
Appendix 1

Model Equation Structure

1. Representative Agent and Final Demand

1.1 Utility Function

$U=U\left(\Gamma, \Lambda_{L}\right)$

$\mathrm{U}=$ utility function

$\Gamma=$ composite good

$\Lambda_{L}=$ leisure

1.2 Composites of final demands

$\Gamma=\Gamma\left(\mathrm{X}_{1}, \ldots \ldots, \mathrm{X}_{\mathrm{N}}\right)$

$\mathrm{X}_{i}(i=1, \ldots \ldots, \mathrm{N})=$ consumer demands for final goods

1.3 Consumer income

$\left.\mathrm{Y}=\sum_{f=1}^{F} \omega_{f}\left(\mathrm{E}_{f}-\Lambda_{f}\right)+\mathrm{Z}+\mathrm{T}\right)$

$\mathrm{Y}=$ consumer income $\mathrm{Y}$ comes from 3 sources, namely, factor endowment income (net of leisure)

$\mathrm{Z}=$ foreign exchange endowment (in domestic currency)

$\mathrm{T}=$ government tax transfer

$\omega_{f}=$ factor prices

$\mathrm{E}_{f}-\Lambda_{f}=$ factor endowments (net of leisure)

\subsection{Budget Constraint}

$\sum_{i=1}^{\mathrm{N}} \Pi_{i F} \mathrm{X} i \leq \mathrm{Y}$

$\Pi_{i F}=$ consumer prices of final goods $\mathrm{Xi}$

1.5 Ad-valorem taxes on final demands

$\Pi_{i F}=\Pi_{i}\left(1+t_{i}\right)$

$\Pi_{i}=$ producer prices

$t_{i}=$ ad-valorem taxes

\section{Firms and Production}

2.1 Multi-output production function

$Q_{k}\left(y_{1 k} \ldots . y_{\mathrm{N} k}\right)=F_{k}\left(\bar{A}_{k}, \gamma_{k}\right)$

$\bar{A}_{k}=$ composite intermediate goods 
$\gamma_{k}=$ value-added

\subsection{Composites of intermediate inputs}

$\bar{A}_{k}=\bar{A}_{k}\left(A_{1 k}, \ldots . A_{N k}\right)$

$A_{1 k}, \ldots . A_{N k}=$ Intermediate inputs

\subsection{Composites of primary factors}

$\gamma_{k}=\gamma_{k}\left(b_{1 k}, \ldots . b_{F k}\right)$

$b_{1 k}, \ldots . . b_{F k}=$ primary factor inputs

2.4 Domestic-export transformation

$y_{i k}=y_{i k}\left(\bar{q}_{\mathrm{ik}}, \mathrm{q}_{\mathrm{ik}}\right)$

$y_{i k}=$ unfinished output goods

$\bar{q}_{\mathrm{ik}}=$ finished goods for the domestic market

$\mathrm{q}_{\mathrm{ik}}=$ finished goods for the export market

\subsection{Ad-valorem taxes on primary factors}

$\omega_{f}=\omega_{f}\left(1+\lambda_{f}\right)$

$\omega_{f}=$ producer factor price

$\lambda_{f}=$ ad-valorem factor tax

2.6 Ad-valorem taxes on intermediate inputs

$\Pi_{i k}=\Pi_{i}\left(1+\sigma_{k}\right)$

$\Pi_{i k}=$ producer intermediate price

$\Pi_{i}=$ market price for intermediate inputs

$\sigma_{k}=$ ad-valorem intermediate tax

\subsection{Zero profit conditions}

$\left.\sum_{i=1}^{N} P_{i} \bar{q}+\sum_{i k}^{N} \bar{P}_{i} q_{i k}=\sum_{i=1}^{N} \Pi_{i k} A_{i k}+\sum_{i=1}^{F} \omega_{f} b_{f k}\right)$ 
3. Trade and Import Aggregation

3.1 Domestic-import Armington aggregation

$\Phi_{i}=\Phi_{i}\left(x_{i}, M_{i}^{\omega}\right)$

$\Phi_{i}=$ domestic-import Armington aggregation

$M_{i}^{\omega}=$ world imports

$x_{i}=$ domestic goods

3.2 Prices of exports (with trade taxes)

$p_{i}^{c \omega}=p_{i}^{c}\left(1+\tau_{x}^{c \omega}\right)\left(1+\bar{\tau}_{m}^{c \omega}\right)$

$\tau_{x}^{c \omega}=$ export tax imposed by CAN on goods originating from CAN to ROW

$\bar{\tau}_{m}^{c \omega}=$ import tax imposed by ROW on that same goods from CAN to ROW

$p_{x_{i}}=p_{i}\left(1+\tau_{x}\right)\left(1+\bar{\tau}_{m}\right)$

3.3 Prices of imports (with trade taxes)

$$
\begin{aligned}
& p_{i}^{\omega c}=\bar{p}_{i}^{\omega}\left(1+\bar{\tau}_{x}^{\omega c}\right)\left(1+\tau_{m}^{\omega c}\right) \\
& p_{m_{i}}=\bar{p}_{i}\left(1+\bar{\tau}_{x}\right)\left(1+\tau_{m}\right)
\end{aligned}
$$

\section{Rest of World}

4.1 Import production technology

$v_{i}=\alpha_{i} m_{i}$

$v_{i}=$ total foreign exchange required to import the amount $m_{i}^{\omega c}=m_{i}$ from ROW to CAN.

$\alpha_{i}=$ constant foreign exchange price of importing goods i from ROW (source w) to

CAN (destination c)

\subsection{Export production technology}

$\mu_{i}=\gamma_{i} M_{i}^{\omega}$

$\mu_{i}=$ total foreign exchange earned from exporting the amount $M_{i}^{\omega}$ from CAN to ROW.

$\gamma_{i}=$ price (in foreign currency) of exporting goods i from CAN (source c) to ROW (destination w) 
4.3 Foreign exchange rate

$\bar{p}_{i}=\alpha_{i} \Omega$

$\alpha_{i}=$ price of imports (in foreign currency)

$\Omega=$ foreign exchange rate

4.4 Zero profit condition of import production technology

$\Omega v_{i}=\bar{p}_{i} m_{i}$

\section{Accounting Identities}

5.1 Balance of payments

$\mathrm{Z}=\Omega \xi$

$\mathrm{Z}=$ amount of foreign exchange endowment (in domestic currency)

$\xi=$ domestic currency equivalence of the amount of foreign exchange

\subsection{Government tax revenue}

$T=\sum_{i=1}^{N} \Pi_{i} X_{i} t_{i}+\sum_{k=1}^{K} \sum_{f=1}^{F} \omega_{f} b_{f k} \lambda_{f}+\sum_{k=1}^{K} \sum_{i=1}^{N} \Pi_{i} A_{i k} \sigma_{k}+\sum_{i=1}^{N} \bar{p}\left(1+\bar{\tau}_{x}\right) m_{i} \tau_{m}+\sum_{i=1}^{N} p_{i} M_{i}^{\omega} \tau_{x}$

$\mathrm{T}=$ amount of government tax transfer

\section{Market Clearing}

6.1 Market clearing for Armington composites

$\sum_{k=1}^{K} A_{i k}+X_{i}=\Phi_{i}$

6.2 Market clearing for finished goods (domestic)

$x_{i}=\sum_{i=1}^{K} \bar{q}$

6.3 Market clearing for finished goods (export)

$M_{i}^{\omega}=\sum_{i=1}^{K} q_{i k}$

6.4 Market clearing for primary factors

$\sum_{k=1}^{K} b_{f k}=E_{f}+\Lambda_{f}$

6.5 Market clearing for foreign exchange

$\xi+\sum_{i=1}^{N} \mu_{i}=\sum_{i=1}^{N} \nu_{i}$ 
Appendix 2:

A2.1 Key to Acronyms:

\section{GOODS}

CTG "Cattle and calves",

PGG "Hogs",

PLG "Poultry",

ANG "Other live animals",

MKG "Fluid milk, unprocessed",

OVG "Eggs in the shell",

MPG "Beef, pork, other meat, fresh, chilled, frozen",

MRG "Prepared meat products",

FLG "Animal fat and lard",

PPG "Poultry, fresh, chilled, frozen",

AFF Agriculture forestry and fishing",

MIN "Mining",

FUE "Mineral fuels (No

Petroleum)"

MFT "Meat, Fish, Vegetable, food tobacco",

OSM "Other Secondary MFG",

MEV "Machinery equipment and Vehicles"

CON "Construction"

TRS "Transportation and storage"

UTL "Utilities (includes ELY)"

CSV "Commercial Services"

SSV "Social and Govt services"

ITX "Indirect taxes (all)",

SUB "Subsidies (all)",

FACTORS

LAB "Labour",

MIX "Mixed Income",

CAP "Profits and Other returns"

\section{SECTORS}

OAS "Other animals and cropsNON SUPPLY MGD",

ACS "Pesticides, fertilizer and other agricultural chemical manufacturing",

DMS "Dairy product manufacturing",

MMS "Meat product manufacturing",

SMS "Supply mgd sectormlk,chk,tur,egg",

PRI "Primary (agr, for, fish)",

MIN "Mining",

UTL "Utilities",

CON "Construction",

FFM "Food and Feed

Manufacturing",

PMF "Primary Manufacturing"

MEV "Machinery Equipment

Vehicles"

WRT "Wholesale, retail trade",

TRN "Transportation and storage",

CIA "Cul, Inf, Adv, Ent., Trav.",

CSV "Other Commercial services",

SSV "Soc, educ and gov services" 


\begin{tabular}{|c|c|c|c|c|c|c|c|c|c|c|c|c|c|c|c|c|c|}
\hline INPUT & UTL & MIN & MEV & CON & CSV & SSV & OAS & ACS & DMS & MMS & SMS & PRI & FFM & PMF & WRT & TRN & CIA \\
\hline UTL & 109.0 & 1651.2 & 1353.3 & 490.2 & 16250.7 & 9305.8 & 816.9 & 187.6 & 78.8 & 181.5 & 125.0 & 103.7 & 638.2 & 8367.8 & 8487.4 & 2027.6 & 3668.7 \\
\hline MIX & 12.0 & 180.0 & 96.9 & 6019.0 & 41289.0 & 12297.0 & 1310.8 & 1.0 & 12.0 & 3.9 & 366.2 & 1088.9 & 62.0 & 300.9 & 4392.0 & 2344.0 & 755.0 \\
\hline CTG & & & 0.8 & 0.1 & 0.2 & 0.2 & 1316.8 & 0.1 & 0.1 & 4803.9 & 35.2 & & 0.4 & 1.0 & 4.9 & 0.2 & \\
\hline PGG & & & 0.8 & & 0.1 & 0.1 & 41.6 & 0.1 & 0.1 & 3085.9 & 0.4 & & 0.3 & 1.1 & 1.9 & 0.1 & \\
\hline PLG & & & 0.7 & & 0.1 & 0.1 & 172.8 & 0.1 & & 1333.9 & 217.2 & & 0.5 & 1.0 & & 0.1 & 0.1 \\
\hline ANG & & & 0.7 & & 18.2 & 0.1 & & 0.1 & 0.1 & 99.9 & & & 0.4 & 0.9 & & 0.1 & \\
\hline MKG & & & 0.6 & & 0.1 & 0.1 & & & 4144.1 & & & & 0.1 & 0.6 & & & \\
\hline OVG & & & 0.9 & & 191.1 & 0.1 & 0.4 & & 0.1 & & 0.5 & & 92.0 & 0.9 & & 0.1 & \\
\hline MPG & & & 0.3 & & 2643.0 & & & & & 2228.9 & & & 122.0 & & 5.9 & 0.1 & \\
\hline MRG & & & 0.4 & & 729.0 & & & & & 11.9 & & & 71.8 & & & 0.1 & \\
\hline FLG & & & 0.3 & & 19.0 & & & & & 24.9 & & & 95.9 & 12.9 & 1.1 & 0.1 & \\
\hline PPG & & & 0.4 & & 676.0 & & & & & 1388.9 & & & 60.9 & & & 0.1 & \\
\hline AFF & 14.1 & 0.4 & 418.0 & 712.6 & 809.3 & 442.8 & 5666.0 & 1.0 & 0.2 & 10.1 & 1570.9 & 1858.0 & 6376.9 & 10156.1 & 74.1 & 6.5 & 3.9 \\
\hline MIN & 160.2 & 3935.2 & 229.5 & 6734.6 & 14.1 & 169.9 & 11.1 & 13.1 & 0.1 & 12.9 & & 6.2 & 40.3 & 8492.2 & 4.2 & 33.9 & 1.9 \\
\hline FUE & 4450.0 & 1790.4 & 604.7 & 1234.6 & 3535.2 & 2066.1 & 1088.3 & 589.0 & 48.8 & 81.6 & 98.7 & 542.5 & 376.1 & 28093.0 & 3003.7 & 6399.9 & 303.3 \\
\hline MFT & 0.3 & 1.0 & 3973.5 & 9.5 & 8949.0 & 29.2 & 3272.0 & 0.5 & 1754.4 & 259.7 & 894.2 & 58.3 & 8340.3 & 486.5 & 246.0 & 108.8 & 116.3 \\
\hline OSM & 48.5 & 1621.7 & 21065.5 & 29255.0 & 34314.0 & 7887.9 & 3505.7 & 806.2 & 614.5 & 606.2 & 181.1 & 418.3 & 4849.1 & 85096.5 & 3393.3 & 703.9 & 3681.5 \\
\hline MEV & 785.9 & 2262.0 & 84125.8 & 9012.6 & 27606.9 & 4775.3 & 339.0 & 39.8 & 0.2 & 0.2 & 27.4 & 462.9 & 36.9 & 5014.7 & 261.4 & 2330.4 & 2664.3 \\
\hline CON & 855.0 & 797.2 & 385.9 & 71.0 & 8235.0 & 5008.0 & 724.8 & 6.0 & 9.9 & 14.0 & 143.2 & 103.0 & 74.0 & 3255.2 & 539.0 & 1486.0 & 460.7 \\
\hline TRS & 341.0 & 581.1 & 2147.4 & 1856.6 & 11499.9 & 3076.2 & 692.4 & 141.0 & 431.6 & 213.8 & 178.6 & 401.7 & 1129.4 & 7218.7 & 2049.8 & 40437.7 & 341.4 \\
\hline CSV & 3604.0 & 17589.3 & 31168.5 & 26277.1 & 163021.4 & 54421.2 & 4084.1 & 379.4 & 1045.0 & 1572.2 & 993.9 & 4014.5 & 9252.7 & 44340.6 & 53298.3 & 15112.5 & 24563.5 \\
\hline SSV & 469.0 & 37.0 & 42.8 & 407.0 & 414.0 & 26237.5 & 71.9 & & & & 20.1 & 15.9 & 1.1 & 7.0 & 9.0 & 204.0 & 147.0 \\
\hline ITX & 1735.0 & 1386.0 & 1381.8 & 5270.0 & 36528.0 & 6465.8 & 1244.3 & 24.0 & 47.0 & 81.8 & 347.7 & 410.8 & 449.8 & 3316.6 & 6844.0 & 4276.0 & 2268.0 \\
\hline SUB & -3031.0 & -132.0 & -204.2 & -85.0 & -1903.0 & -1972.2 & -3218.6 & & -41.0 & -8.2 & -297.4 & -79.2 & -48.2 & -267.4 & -362.0 & -2271.0 & -1216.0 \\
\hline LAB & 6313.0 & 11564.0 & 30776.8 & 38848.0 & 129383.0 & 151954.8 & 3022.8 & 274.0 & 978.0 & 2407.8 & 494.2 & 3956.8 & 6814.8 & 55784.6 & 75617.0 & 29051.0 & 22776.0 \\
\hline CAP & 19137.0 & 46702.0 & 21910.9 & 6767.0 & 99155.0 & 24556.9 & 6988.4 & 402.0 & 1487.0 & 1061.9 & 1952.6 & 2054.9 & 9605.9 & 44037.8 & 23259.0 & 13088.0 & 16819.0 \\
\hline
\end{tabular}


A2.3- Output Table

\begin{tabular}{|c|c|c|c|c|c|c|c|c|c|c|c|c|c|c|c|c|c|}
\hline OUTPUT & UTL & MIN & MEV & CON & CSV & SSV & OAS & ACS & DMS & MMS & SMS & PRI & FFM & PMF & WRT & TRN & CIA \\
\hline UTL & 33667.0 & 64.3 & 0.7 & 46.1 & 2906.2 & 6052.3 & & 61.0 & 0.1 & & & 0.2 & 0.5 & 285.1 & 0.1 & 9031.5 & 32129.2 \\
\hline CTG & & & & & & 3.8 & 7505.6 & & & & 281.4 & & & 0.1 & & & \\
\hline PGG & & & & & & & 3788.3 & & & & 54.7 & & & 0.2 & & & \\
\hline PLG & & & 0.1 & & & & 64.4 & & & & 1696.6 & & 0.1 & & 0.1 & & \\
\hline ANG & & & & & & 1.1 & 381.1 & & & & 3.9 & 0.1 & 0.1 & 0.1 & & & \\
\hline MKG & & & 0.3 & 0.1 & 0.1 & 0.2 & 90.2 & & 0.1 & & 4062.8 & & 0.2 & 0.4 & & 0.1 & 0.1 \\
\hline OVG & & 0.1 & & & & & 20.1 & & & & 530.9 & & & & & & \\
\hline MPG & & & & & & 0.2 & 233.0 & & & 10278.9 & & & & 0.1 & 15.0 & & \\
\hline MRG & & 0.1 & 0.2 & & & 0.1 & & & & 2451.9 & & & 215.0 & 0.2 & 9.0 & & \\
\hline FLG & & & 0.3 & 0.1 & 0.1 & 0.1 & & & & 233.9 & & 0.1 & 0.1 & 6.4 & & 0.1 & \\
\hline PPG & & & 0.3 & & & 0.1 & 2.6 & & & 3904.9 & 68.4 & & 0.1 & & & & \\
\hline AFF & 29.0 & 0.8 & 704.4 & 0.5 & 1525.3 & 21.9 & 17712.8 & & 0.7 & & 640.2 & 14489.2 & 96.6 & 336.1 & 55.5 & & \\
\hline MIN & & 20700.1 & 2.8 & 132.4 & 1.0 & 12.1 & 0.1 & 14.0 & 0.4 & & & 0.6 & 1.1 & 431.7 & 13.5 & 1.6 & 0.6 \\
\hline FUE & & 61449.2 & 0.8 & 0.1 & 6.2 & 33.0 & & & 0.2 & & & 0.2 & 0.5 & 29951.2 & 156.1 & 0.5 & 0.3 \\
\hline MFT & & 1.6 & 457.8 & 9.3 & 7174.6 & 109.0 & 604.5 & & 9818.5 & 2108.9 & 10.5 & 27.1 & 42684.2 & 4350.1 & 983.9 & 55.2 & 624.9 \\
\hline OSM & 1.0 & 5891.6 & 6898.0 & 2.9 & 334.1 & 387.1 & 438.0 & 2587.0 & 113.0 & 10.9 & & 311.3 & 2117.9 & 226800.4 & 2096.5 & 16.1 & 10396.2 \\
\hline MEV & & 915.6 & 181772.1 & 1.2 & 37.0 & 11.5 & & 13.0 & 3.7 & 4.9 & & 7.3 & 100.9 & 24968.6 & 1477.1 & 825.3 & 447.6 \\
\hline CON & & 0.1 & 0.1 & 131783.0 & & 0.1 & & & 0.1 & & & & 0.2 & 0.2 & & 0.1 & \\
\hline TRS & & 0.7 & 1.7 & 0.3 & 6713.9 & 1740.3 & 287.1 & & 0.1 & & & 249.4 & 1.2 & 3.6 & 52.2 & 101518.2 & 7.5 \\
\hline CSV & 1306.0 & 942.0 & 9642.7 & 903.8 & 564679.8 & 26052.4 & 23.7 & 190.0 & 674.0 & 483.3 & 0.3 & 331.7 & 3224.1 & 16583.3 & 176270.9 & 3891.4 & 33748.2 \\
\hline SSV & & 0.3 & 0.7 & 0.2 & 0.1 & 272297.6 & & & 0.1 & & & & 0.8 & 1.2 & 0.1 & 0.1 & 0.1 \\
\hline
\end{tabular}


21

A2.4- Final Demand Table

\begin{tabular}{lrrrr}
\hline Final Demand & \multicolumn{1}{c}{ PEX } & GOV & \multicolumn{1}{c}{ INV } & \multicolumn{1}{c}{ NETX } \\
\hline UTL & 27895.9 & & & 2505.0 \\
CTG & 237.0 & & 2.0 & 1388.0 \\
PGG & 95.7 & & 90.0 & 525.0 \\
PLG & 34.7 & & 7.0 & -7.0 \\
ANG & 121.9 & & 58.0 & 86.0 \\
MKG & 9.0 & & & \\
OVG & 303.0 & & & -38.0 \\
MPG & 2750.0 & & -90.0 & 2867.0 \\
MRG & 1986.3 & & 1.0 & -124.0 \\
FLG & & & -1.0 & 88.0 \\
PPG & 1944.1 & & 30.0 & -124.0 \\
AFF & 6952.5 & & -394.4 & 934.0 \\
MIN & 419.1 & & -1349.5 & 2383.0 \\
FUE & 12213.6 & & -1109.2 & 26188.0 \\
MFT & 40416.7 & & -236.1 & 340.0 \\
OSM & 35839.1 & 712.0 & 2262.9 & 21539.0 \\
MEV & 42086.7 & 4650.0 & 51007.4 & -26904.0 \\
CON & & 17680.0 & 91936.0 & \\
TRS & 19445.9 & 56.0 & 620.0 & 17716.0 \\
CSV & 340511.4 & 3475.0 & 28566.0 & 11657.0 \\
SSV & 32537.0 & 211708.0 & & -27.0 \\
ITX & 59548.0 & 682.0 & 8301.0 & 3050.0 \\
\hline
\end{tabular}

